\title{
Corruption and Bribery on Transition Economies: Case Study for SEE Countries
}

\author{
Doi:10.5901/ajis.2015.v4n2p45
}

\author{
Jeton Zogjani, MSc \\ zogjanijeton@gmail.com
}

\author{
Malësor Kelmendi, MSc \\ malsor_kelmendi@hotmail.com
}

\begin{abstract}
In this research paper is analyzed corruption and bribery on transition economies with case study of SEE countries and the main theoretical arguments for discussions are as following: the effect of corruption in economic growth, mobilization of different countries or institutions against corruption (prevent corruption through institutional policies and anti - corruption programs), the level of corruption in SEE countries, effect of corruption in public sector and in economic efficiency. In methodology, the secondary data that used are collected from international institutions and they are calculated through STATA program. The main analyses are descriptive statistic, OLS method of regression and correlation matrix. The variables that are used in research paper are: corruption and bribery \& bureaucracy costs (as dependent variable), then economic growth, political stability, economic freedom, transition reforms and education index (as independent variables). Based on empirical results, in the OLS analysis is found that corruption has positive impact on economic growth but bribery and has negative impact on economic growth of SEE countries then in T-statistic analysis all independent variables have shown negative significance $(T<2)$ on corruption and bribery. In correlation methods, economic growth has higher negative correlation with bribery than with corruption. In conclusion, all of SEE countries must attempt to fight against corruption and it is very serious problem for economic sustainable, political stability and institutional consolidation, process of integration and in other important challenges. In fact, corruption index in 2014 shown that the most of SEE countries are ranking under 50 out 100, it means high level of corruption.
\end{abstract}

Keywords: growth, index, regression analyses, STATA program, transition reforms

\section{Introduction}

In the recent decades, corruption is become the most important issue for transition economies. During the transition processes in SEE countries, corruption has been constantly a phenomenon accompanying from communist regime to liberalization markets. It has had an effect on low institutional performance, lack of transparency in public sector and distrust of the citizens towards in government institutions, (SELDI Report, 2002) \& (Svendsen, G.T., 2003). Also, in transition economies were constantly faced with different crisis from Euro zone and global financial crisis then corruption has bring more damage and trouble in these economies, (Sanfey, P. \& Zeh, S., 2012). According to (World Bank Report, 2011) corruption has not been only obstacle in SEE economies, so as other obstacle identified bribery (administrative bribes) and unofficial payments in very sensitive institutions, such as: areas of taxes, customs, imports and courts but recently SEE countries have started to improve in context of bribery. But most of SEE countries are oriented to prevent or fight corruption (bribery) through three general categories: fight against corruption by government institutions (different agencies), different structural reforms in institutions for reducing corruption, membership in international organization (such as: UN, EU) to prevent corruption, (Ewoh et al, 2013).

\section{A Review of Selected Literature}

Large and persistent differences of corruption across transition countries are a challenging research issue, (Sah, 2007), for this reason the corruption activities for transition countries have been interesting for research since middle of the 1990's. In fact, this period represented the time when transition countries started economic transformation and corruption was an integral part of the process of economic transition in these countries. Corruption has reflected in various indicators of economy, such as: in reducing the level of FDI and domestic investment, the embezzlement of public funds, lower productivity in growth, decline of capital accumulation and growth, etc; (Jimenez, M.D.M.S \& Jimenez, J.S, 2007) \& (Blackburn, K. \& Powell, J, 2011). Also corruption (through bribe paying) hampers international trade particular in countries with high export rate (De Jong, E. \& Bogmans, Ch, 2011). As argued (Farooq et al, 2013) \& (Osipian, 2012), in long time relationship, corruption impedes economic growth especially in financial development (weakens the financial 
capital), free trade (reduces domestic production) and human development (reduces the level of human capital and slowing the pace of its development), etc.

For this reason different international institutions invited countries with high level of corruption for fighting through institutions government policies and for preventing through other non-government institutions. As argued (Khoman, 2015), the corruption was involved in many countries in the world, including departments from simple administrative services to complex corruption (political favors for corruption), this form of corruption is widespread and pernicious. According to Ban Kim Mon's message (United National Secretary General) on International Anti - Corruption Day "corruption is a threat to development, democracy and stability in global aspect" and this will be the biggest challenge in the future (United Nation, 2010), so preventing corruption by government institution and other relevant institutions is the most important issue in transition countries. Most of transition countries have ratified anti - corruption programs by national parliaments (Michael, B, 2010) but the problem is that anti - corruption programs are not being implemented (anti-corruption legal work has not yet succeeded their execution) by different political and business pressure.

Corruption can affect anywhere in different ways: macro environment (where correlation with corruption is from 0.40 to 0.45 ), economic development, socio - cultural factors, political / legal stability (Judge et al, 2011) and fighting corruption is a political criteria for transition countries to integration into international organization (EU). As argued by (Dzhumashev, 2014) \& (Graeff, P. \& Mehlkopb, G, 2003), the significant effect in corruption outcomes are these important factors: the quality of governance, the level economic performance, the size of public spending, economic freedom, etc. This means that the greater level of these factors will have the lower impact of corruption and in otherwise the impact of corruption will be higher. Many authors have research the relationship between corruption and economic growth and most of them agreed that the corruption have negative impact in economic growth (Mauro, P, 1997) \& (Mo, 2001) \& (Aidt, 2009) Other authors argued that exist a negative rate of correlation between corruption and the average rate of per-capita income growth in countries with democratic regime (Mendez, F. \& Sepulveda, F, 2006) also countries with capital account liberalization (financial openness) and government corruption has a negative impact on growth (Kunieda et al, 2014).

\subsection{Effect of Corruption in Transition Countries}

Corruption has been one of the major problems for transition countries over few recent decades particularly after transformation from command economy to global market economy. According to (World Bank, 2004), estimates about corruption (bribes pay) in every year is over US \$ 1 trillion and countries that fight or prevent corruption through institutional policies and anti - corruption programs could improve their capita incomes by 400 percent, it continues to be one of the biggest challenges for global countries in modern economy. In some countries is very hard to overcome the problem of corruption because corruption has managed to have a large extent inside of different departments.. According to (Transparency International Report, 2014), most of SEE countries have scored below levels (50 out of 100), that shows a serious problem of corruption, while the lowest level of corruption in global index is in Denmark (92 out of 100) and the highest level of corruption in global index has Somalia (8 out of 100), for further detail see table below.

Table 1. Index of Corruption in SEE Countries 2012 - 2014

\begin{tabular}{|cccc|}
\hline Country: & 2014 & 2013 & 2012 \\
\hline Albania & 31 & 31 & 33 \\
\hline Bosnia and Herzegovina & 39 & 42 & 42 \\
\hline Bulgaria & 43 & 41 & 41 \\
\hline Croatia & 48 & 48 & 46 \\
\hline Czech Republic & 51 & 48 & 49 \\
\hline Greece & 43 & 40 & 36 \\
\hline Hungary & 54 & 54 & 55 \\
\hline Kosovo & 33 & 33 & 34 \\
\hline Montenegro & 42 & 44 & 41 \\
\hline Romania & 43 & 43 & 44 \\
\hline Serbia & 41 & 42 & 39 \\
\hline Slovakia & 50 & 47 & 46 \\
\hline The FYR of Macedonia & 45 & 44 & 43 \\
\hline Average Score: & 43.3 & 42.8 & 42.2 \\
\hline
\end{tabular}

Source: Transparency International Report 2014, 2013, 2012 
If we refer table above, we can understand that the level of corruption on SEE countries has increased year by year from 2012 to 2014 but in the SEE countries 10 from 13 countries that are including in table above have the average score of corruption in $43.3 \%$. According to (Transparency Report, 2013) about $69 \%$ of global countries have higher level of corruption (the index of corruption is under 50 out of 100). Regardless of the continuous progress across SEE countries and the establishment of a democratic political system on the one hand and lack of trust in the political system and increasing level of corruption in these countries on the other hand, signifies that corruption can bring one of the most serious threats for democracy, sustainability and stability in the countries of SEE, (McDevitt, 2013). The effects of corruption manifested between sector public (government institution) and private sector (people and private business). According to (SELDI Report, 2013) \& (Karklins, 2002) the corruption in SEE countries has shown two main types: a) "grand corruption" - the highest level of corruption in institutions (like as: top state officials, politicians, and business people, etc); "petty corruption" - includes simple administrative service in government institution (like as: bribing traffic cops, building inspectors, etc) and the second type associates with smaller payment and favors, gifts, etc.

Many of research publications have suggested that corruption in transition economies has involved a lot of factors, such as government size, juridical system, education, religion, degree of economic freedom, welfare, geographic size of a country, (Goel, R.K. \& Budak, J, 2006). These factors have reduced economic efficiency and overall economic performance. They have a direct negative implication in growth of SEE countries, (Budak, J. \& Goel, R.K, 2004). In many of transition countries in the world a centralized administrative system has become a perfect opportunity to develop the corruption (Iwasaki, I. \& Suzuki, T., 2010) while in countries that have the political institutions with high quality, corruption has a significant negative impact on economic growth, (Sena et al, 2008) but in countries with low-quality (less effective) institutions, corruption is less detrimental to economic efficiency (Meon, P.G. \& Weill, L, 2010). The recent results show that the level of corruption will decline in SEE countries, if these countries include these important components: freedom economic (Pieroni, L. \& d'Agostino, G, 2013), structural reform (Abed, G.T. \& Davoodi, H.R, 2000) as well as economic performance (growth, inflation, the fiscal balance and FDI). This leads to structural reforms that dominate over the effect of corruption in SEE countries, (Abed, G.T. \& Davoodi, H.R, 2000).

\section{Methodology and Selected Data}

In order to estimate the effect of corruption (bribery and bureaucracy) on transition countries, in case of SEE countries are used secondary data. They are collected by different international institutions (such as: World Bank, EBRD, IMF and Transparency International). Used data in research included the most of SEE countries (see Appendix 1/A) and most of variables that are used are from annual reports of 2014 (see Appendix 1/B). The main variables are: depend variables (corruption and bribery and bureaucracy costs) and independent variables (Economic Growth, Political Stability, Rule of Law, Economic Freedom, Transition Reform and Education Index). Data are calculated through program STATA (econometric - statistic program) then the main analyses are as following: descriptive statistics methods, multiple regression analysis and correlation method. The econometric models is to analyze the relationship between corruption (and Bribery \& Bureaucracy) on economic growth and they are based on the following equations: $\operatorname{Ln}(\mathrm{Clt})++\operatorname{Ln}(B B t)=\beta 0$ $+\beta 1 \ln (E G t)+\beta 2 \ln (P S t)+\beta 3 \ln (R L t)+\beta 4 \ln (E F t)+\beta 5 \ln (T R t)+\beta 6 \ln (E l t)+\varepsilon t$. Where the main variables for analyses are as following:

- $\mathrm{Cl}=$ Corruption Index;

- $\mathrm{BB}=$ Bribery and Bureaucracy costs;

- $\quad E G=$ Economic Growth;

- $P S=$ Political Stability;

- $\mathrm{RL}=$ Rule of Law;

- $\quad \mathrm{EF}=$ Economic Freedom;

- $\quad \mathrm{TR}=$ Transition Reform;

- $\quad E l=$ Education Index;

- $\varepsilon \mathrm{t}=$ Stochastic Error Term;

- $\beta 0, \beta 1, \beta 2, \beta 3$, are the respective parameters; 


\section{Empirical Results}

This part of research paper reflects the results of analysis, they are calculated through econometric program STATA. In fact, this is the most important part because here are interpreted the implications of the parameters (variables) that are involved in research paper with different methods (Statistic descriptive, Correlation method, Ordinary Least Squares method). In table 2 is Descriptive Statistic, which is a method for quantitative analysis data and it is used to describe the basic features of the data in a research paper. Most of variables that are included in research paper have 14 observations. The main analyses in table 2 are as following: the minimum value of the perceived level of corruption index is 33 (it means, the lowest value of "Cl" in period of research) and maximum value is 58 (it means, the highest value of " $\mathrm{Cl}$ " in period of research), the value of mean is 44.5 (it means, average value of "Cl" in period of research) and standard deviation values is 7.22 (it means, how many the "Cl" variable are quite close between 33 to 54 ).

Table 2. Descriptive Statistic

\begin{tabular}{|l|c|c|c|c|c|}
\hline Variables: & Observations & Std. Dev. & Min & Mean & Max \\
\hline Corruption Index & 14 & 7.22 & 33 & 44.5 & 58 \\
\hline Bribes \& Bureaucracy & 12 & 3.45 & 15.3 & 20.9 & 26.2 \\
\hline Economic Growth & 14 & 1.89 & -3.3 & 0.9 & 3.1 \\
\hline Political Stability & 14 & 0.61 & -0.9 & 0.2 & 1.1 \\
\hline Rule of Law & 14 & 0.68 & -1.7 & 0.1 & 1.0 \\
\hline Economic Freedom & 13 & 0.28 & 6.6 & 7.2 & 7.6 \\
\hline Transition Reform & 12 & 0.32 & 2.8 & 3.4 & 3.8 \\
\hline Education Index & 13 & 0.10 & 0.6 & 0.7 & 0.9 \\
\hline
\end{tabular}

Source: Authors

The value of Bribes and Bureaucracy costs variable are: the minimum is 15.3, maximum is 26.2 then value of mean and standard deviation are 20.9 respectively 3.45. Economic growth has values of minimum -3.3, maximum 3.1, mean 0.9 and standard deviation 1.89. The values of Political stability are as following: minimum and maximum $-0.9 \& 1.1$ then mean and standard deviations are $0.2 \& 0.61$. Rule of Law have these values: minimum is -1.7 , maximum is 1.0 then mean is 0.1 and standard deviation is 0.68 . The value of minimum and maximum of Economics freedom are 6.6 respectively 7.6 then mean values is 7.2 and standard deviation is 0.28 . Transition reforms have minimum value 2.8 , maximum values 3.8 and mean 3.4 and standard deviation 0.32 . In this research paper the values of Education Index are lowest from other variables: the minimum is 0.6 and maximum is 0.9 then mean is 0.7 and standard deviation is 0.10 . The Table 3 is the most important analysis, and the OLS method analyzes the additional explanatory factors (or independent variables) have a systemic effect on the dependent variable. The main variables that are included in research paper are two dependent variables (corruption and bribery \& bureaucracy) and other independent variables (Economic Growth, Political Stability, Rule of Law, Economic Freedom, Transition Reform and Education Index).

In OLS method are realized two regression analysis between dependent variables and independent variables: The first regression analysis is between corruption and independent variables and the results have found that Economic Growth has positive impact $(\beta 1=0.74)$ on corruption. Explanation of result with positive impact is as following: when other variables in analysis (Political Stability, Rule of Law, Economic Freedom, Transition Reform and Education Index) are fixed or constant and when the economic growth increase for a unit, it will have effect in corruption with 0.74 per unit (positive impact). Also Rule of Law $(\beta 3=2.31)$, Transition Reform $(\beta 5=13.72)$ and Education Index $(\beta 6=65.20)$ have positive impact on corruption. But the Political Stability has negative impact $(\beta 2=-6.95)$ on corruption. Explanation of results with negative impact is as following: when other variable that are included in analysis are fixed (constant) and when the political stability increase for a unit, it will have effect in corruption with - 6.95 per unit (negative impact). Also Economic Index has negative impact $(\beta 4=6.83)$ on corruption.

Through T-statistics, we can understand the explanatory capability (or significance) that the variables have between them and the significance can be positive $(T>2)$ or negative $(T<2)$. As argue the results in analysis $(P>t)$, all variables that are included in research (Economic Growth 0.47 , Political Stability 0.19 , Rule of Law 0.46, Economic Freedom 0.17, Transition Reform 0.06 and Education Index 0.08) have non - significance $(T<2)$ on corruption. Other important analysis in table 3 is the coefficient of determination $\left(R^{2}\right)$, it measures the correlation between dependent 
variable and independent variables, so the question is: What does mean the determination $\left(R^{2}=0.99\right)$ between Corruption and Economic Growth, Political Stability, Rule of Law, Economic Freedom, Transition Reform and Education Index? It tells us: a) the relationship is positive between them; b) the relationship is quite strong (since the value of determination is pretty close to $1(0.99)$ while $0.01 \%(100 \%$ - 99\%) are other factors that are not included in this model.

Table 3. Test of Ordinary Least Squares (OLS) Method

\begin{tabular}{|l|c|c|c|c|c|c|c|}
\hline Variables: & Coeff. & Std. Err. & $\mathrm{T}$ & $\mathrm{P}>\mathrm{t}$ & [Coeff. & Interv.] & $\mathrm{R}^{2}$ \\
\hline Corruption Index & & & & & & & 0.99 \\
\hline Economic Growth & 0.74 & 0.92 & 0.80 & 0.47 & -1.82 & 3.30 & \\
\hline Political Stability & -6.95 & 4.41 & -1.57 & 0.19 & -19.20 & 5.31 & \\
\hline Rule of Law & 2.31 & 2.81 & 0.82 & 0.46 & -5.50 & 10.12 & \\
\hline Economic Freedom & -6.83 & 4.11 & -1.66 & 0.17 & -18.25 & 4.60 & \\
\hline Transition Reform & 13.72 & 5.20 & 2.64 & 0.06 & -0.71 & 28.15 & \\
\hline Education Index & 65.20 & 27.45 & 2.38 & 0.08 & -11.00 & 141.41 & \\
\hline Variables: & Coeff. & Std. Err. & $\mathbf{T}$ & $\mathbf{P}>\mathbf{t}$ & {$[$ Coeff. } & Interv.] & $\mathbf{R}^{2}$ \\
\hline Bribes \& Bureaucracy & & & & & & & 0.99 \\
\hline Economic Growth & -1.30 & 0.70 & -1.84 & 0.14 & -3.24 & 0.66 & \\
\hline Political Stability & -0.08 & 3.36 & -0.02 & 0.98 & -9.42 & 9.25 & \\
\hline Rule of Law & -3.29 & 2.14 & -1.53 & 0.20 & -9.24 & 2.66 & \\
\hline Economic Freedom & -1.51 & 3.13 & -0.48 & 0.65 & -10.21 & 7.19 & \\
\hline Transition Reform & 5.39 & 3.95 & 1.36 & 0.24 & -5.60 & 16.38 & \\
\hline Education Index & 18.30 & 20.91 & 0.88 & 0.43 & -39.74 & 76.35 & \\
\hline
\end{tabular}

Source: Authors

The second regression analysis in table 3 is between bribery and bureaucracy costs as dependent variable and other independent variables and the results have found that Economic Growth has negative impact $(\beta 1=-1.30)$ on bribery and bureaucracy costs. Also Political Stability $(\beta 2=-0.08)$, Rule of Law $(\beta 3=-3.29)$, Economic Freedom $(\beta 4=-1.51)$ have negative impact on bribery and bureaucracy costs but only Transition Reform $(\beta 5=5.39)$ and Education Index ( $\beta 6=$ 18.30) have positive impact on bribery and bureaucracy costs. In T-statistic analysis the results shown that all independent variables (Economic Growth 0.14, Political Stability 0.98, Rule of Law 0.20, Economic Freedom 0.65, Transition Reform 0.24 and Education Index 0.43 ) are non - significant $(T<2)$ on dependent variable (bribery and bureaucracy costs). In the second regression analysis, the coefficient of determination is $\mathrm{R}^{2}=0.99$ between dependent and independent variables, then the relationship between them is quite strong (since the value of determination is pretty close to $1(0.99)$ while $0.01 \%$ (100\% - 99\%) are other factors that are not included in this model.

In table 4 is Correlation Matrix, it shows the level of relationship between dependent variable and independent variables. The first correlation matrix is between corruption and independent variables and the results shown that economic growth $(-0.25)$ and economic freedom $(-0.35)$ have negative correlation with corruption. Other independent variables (political stability 0.71 , rule of law 0.91 , transition reform 0.59 and education index 0.79 ) have positive correlation with corruption. The second correlation matrix is between bribery and bureaucracy costs and independent variables and the results shown that the same variables, economic growth $(-0.78)$ and economic freedom $(-0.55)$ have the highest negative correlation with bribery and bureaucracy costs than in corruption analysis. Other independent variables (political stability 0.43 , rule of law 0.16 , transition reform 0.03 and education index 0.42 ) have positive correlation with bribery and bureaucracy costs. 
Table 4. Correlation Matrix

\begin{tabular}{|l|c|c|c|c|c|c|c|}
\hline Variables: & Cl & EG & PS & RL & EF & TR & El \\
\hline Corruption Index & 1.00 & & & & & & \\
\hline Economic Growth & -0.25 & 1.00 & & & & & \\
\hline Political Stability & 0.71 & -0.19 & 1.00 & & & & \\
\hline Rule of Law & 0.91 & -0.28 & 0.61 & 1.00 & & & \\
\hline Economic Freedom & -0.35 & 0.50 & -0.02 & -0.23 & 1.00 & & \\
\hline Transition Reform & 0.59 & 0.16 & 0.59 & 0.48 & 0.26 & 1.00 & \\
\hline Education Index & 0.79 & -0.48 & 0.82 & 0.83 & -0.30 & 0.29 & 1.00 \\
\hline Variables: & BB & EG & PS & RL & EF & TR & EI \\
\hline Bribes \& Bureaucracy & 1.00 & & & & & & \\
\hline Economic Growth & -0.78 & 1.00 & & & & & \\
\hline Political Stability & 0.43 & -0.28 & 1.00 & & & & \\
\hline Rule of Law & 0.16 & -0.29 & 0.65 & 1.00 & & & \\
\hline Economic Freedom & -0.55 & 0.49 & -0.22 & -0.28 & 1.00 & & \\
\hline Transition Reform & 0.03 & 0.11 & 0.47 & 0.51 & 0.08 & 1.00 & \\
\hline Education Index & 0.42 & -0.50 & 0.86 & 0.83 & -0.37 & 0.26 & 1.00 \\
\hline
\end{tabular}

Source: Authors

\section{Conclusion}

In this research paper is analysis corruption and bribery \& bureaucracy costs on transition countries with case study of SEE countries. The data used are secondary data and they are collected from international institutions (World Bank, IMF, UNDP and EBRD). The most of data for analysis included one period of time (2014) and data are calculated by STATA program (econometric and statistical software). The main variables in research paper are as following: in one side are corruption and bribery \& bureaucracy costs as depend variables and in other side are economic growths, political stability, rule of law, economic freedom, transition reform and education index as independent variables. The main analyses in research paper include descriptive statistic methods, regression analysis (OLS method). In OLS method and correlation matrix are realized two type of analyses: the first is between corruption and independent variables and the second is between bribery and bureaucracy costs and independent variables.

At the first, the results of regression (OLS) method shown that economic growth $(\beta 1=0.74)$ has positive impact on corruption. Also rule of law ( $\beta 3=2.31)$, transition reform $(\beta 5=13.72)$ and education index $(\beta 6=65.20)$ have positive impact on corruption. Political stability ( $\beta 2=-6.95)$ and economic freedom ( $\beta 2=-6.83$ ) has negative impact on corruption. In Tstatistic analysis, the results shown that all independent variables are non - significant $(T<2)$ on dependent variable. In $T$ statistic analysis the results shown that all independent variables $(\mathrm{T}<2)$ are non-significant on dependent variable and the coefficient of determination in $\mathrm{R}^{2}=0.99$. At the second, the results of regression (OLS) method shown that Economic Growth has negative impact ( $\beta 1=-1.30)$ on bribery and bureaucracy costs. Also Political Stability ( $\beta 2=-0.08)$, Rule of Law $(\beta 3=-3.29)$, Economic Freedom ( $\beta 4=-1.51$ ) have negative impact on bribery and bureaucracy costs. But only Transition Reform ( $\beta 5=5.39)$ and Education Index ( $\beta 6=18.30)$ have positive impact on bribery and bureaucracy costs. In T-statistic analysis the results shown that all independent variables are non - significant $(T<2)$ on dependent variable. Then the coefficient of determination is $\mathrm{R}^{2}=0.99$ between dependent and independent variables.

\section{References}

Abed, G.T. \& Davoodi, H.R. (2000). Corruption, Structural Reform, and Economic Perfomance in the Transition Countries, IMF Working Paper, WP/00/132. Washington D.C: The IMF Office.

Abed, G.T. \& Davoodi, H.R. (2000). Corruption, structural reforms and economic performance in the transition countries, Fiscal Affairs Department. Washington: Internaional Monetary Found, IMF Working Paper WP/00/132.

Aidt, T. (2009). Corruption, institutions, and economic development. Oxford Review of Economic Policy, 25 (2), pp. 271 - 291.

Blackburn, K. \& Powell, J. (2011). Corruption, inflation and growth. Economics Letters, 113, pp 225-227

Budak, J. \& Goel, R.K. (2004). Economic Reforms and Corruption in Transition Countries. 65th Anniversary Conference of the Institute of Economics, November 18 - 19, 2004 (pp. 3 - 19). Zagreb, Croatia: The Institute of Economics. 
De Jong, E. \& Bogmans, Ch. (2011). Does corruption discourage international trade? European Journal of Political Economy, 27, pp. 385 - 398.

Dzhumashev, R. (2014). Corruption and growth: The role of governance, public spending, and economic development. Economic Modelling, 37, pp. 202 - 215.

Ewoh et al. (2013). Corruption, public integrity, and globalization in South-Eastern European states. A comparative analysis. Theoretical and Applied Economics, 20 (1), pp. 7 - 34.

Farooq et al. (2013). Does corruption impede economic growth in Pakistan ? Economic Modelling, 35, pp. 622 - 633.

Goel, R.K. \& Budak, J. (2006). Corruption in transition economies: Effects of government size, country size and economic reforms. Journal of Economics and Finance, 30 (2), pp. 240 - 250.

Graeff, P. \& Mehlkopb, G. (2003). The impact of economic freedom on corruption: different patterns for rich and poor countries. European Journal of Political Economy, 19, pp. 605 - 620.

Iwasaki, I. \& Suzuki, T. (2010). The Determinants of Corruption in Transition Economies, Discussion Paper Series A, No.533. Tokyo: Institute of Economic Research.

Jimenez, M.D.M.S \& Jimenez, J.S. (2007). Corruption, efficiency and productivity in OECD countries. Journal of Policy Modeling, 29, pp. $903-915$.

Judge et al. (2011). The antecedents and effects of national corruption: A meta-analysis. Journal of World Business, 46, pp. 93 - 103.

Karklins, R. (2002). Typology of Post - Communist Corruption. Problems of Post-Communism, 49 (4), pp. 22 - 32.

Khoman, S. (2015). Corruption, Transactions Costs and Network Relationships: Governance Challenges for Thailand. Sustainable Economic Development, pp. 215 - 235.

Kunieda et al. (2014). Corruption, capital account liberalization, and economic growth: Theory and evidence . International Economics, 139 , pp. 80 - 108.

Mauro, P. (1997). Why Worry About Corruption ? Washington D.C: International Monetary Fund, Publication Services, ISBN 1-55775635-x.

McDevitt, A. (2013). Transparency International Report: Buying and Influence - Money and Elections in the Balkans. Berlin: Transparency International.

Mendez, F. \& Sepulveda, F. (2006). Corruption, growth and political regimes: Cross country evidence. European Journal of Political Economy, 22, pp. 82 - 98.

Meon, P.G. \& Weill, L. (2010). Is Corruption an Efficient Grease ? World Development, 38, pp 244-259

Michael, B. (2010). Issues in Anti - Corruption Law: Drafting Implementing Regulations for Anti-Corruption Conventions in Central Europe and the Former Soviet Union. Journal of Legislation, 36, pp. 272 - 296.

Mo, P. (2001). Corruption and Economic Growth. Journal of Comparative Economics, 29, pp. 66 - 79.

Osipian, A. (2012). Education corruption, reform, and growth: Case of Post-Soviet Russia. Journal of Eurasian Studies, 3, pp. 20 - 29.

Sah, R. (2007). Corruption across countries and regions: Some consequences of local osmosis. Journal of Economic Dynamics \& Control, 31, pp. 2573 - 2598.

Sanfey, P. \& Zeh, S. (2012). Making sense of competitiveness indicators in south-eastern Europe, Working Paper No. 145. London: EBRD: Publication Service.

SELDI Report. (2013). SELDI Strategy and Action Agenda for Good Governance and Anticorruption in Southeast Europe. Sofia: Center for the Study of Democracy.

SELDI Report. (2002). Anti - corruption in south east Europe: First steps and policies. Sofia: Center for the Study of Democracy (ISBN 954-477-103-4).

Sena et al. (2008). Governance regimes, corruption and growth: Theory and evidence. Journal of Comparative Economics 36, pp. 195 220.

Svendsen, G.T. (2003). Social Capital, Corruption and Economic Growth: Eastern and Western Europe, Working Paper 03-21. Denmark: Department of Economics.

Transparency International Report. (2014). The Corruption Perceptions Index 2014. Berlin: Transparency International.

Transparency Report. (2013). Transparency International Corruption Perceptions Index. United Kingdom: EYGM Limited (EY - Ernst \& Young).

United Nation. (2010, December 03). Secretary-General Ban Ki-moon's message for International Anti-Corruption Day, observed on 9 December 2010. New York, USA, Press Release (SG/SM/13292-OBV/947), http://www.un.org/press/en/2010/sgsm13292.doc. htm.

World Bank. (2004). Empowering the Poor to Fight Corruption. Retrieved 12 18, 2014, from World Bank: http://web.worldbank.org

World Bank Report. (2011). Trends in Corruption and Regulatory Burden in Eastern Europe and Central Asia. Washington D.C: The World Bank: Publication Service. 


\section{Appendixes}

Appendix 1/A

\begin{tabular}{ccc}
\hline \multicolumn{1}{c}{ List of SEE countries that are including in research paper: } & Romania \\
Albania & Greece & Serbia \\
Bosnia and Herzegovina & Hungary & Slovakia \\
Bulgaria & Kosovo & Slovenia \\
Croatia & Macedonia FRY & \\
Czech Republic & Montenegro & \\
\hline
\end{tabular}

Source: Authors

Appendix 1/B

\begin{tabular}{|c|c|c|c|c|c|c|c|c|}
\hline \multicolumn{9}{|c|}{ Description of data collection and analysis in research paper: } \\
\hline $\begin{array}{l}\text { Names of } \\
\text { Countries }\end{array}$ & $\begin{array}{l}\text { Corrupt Index } \\
\text { (CPI) }\end{array}$ & $\begin{array}{c}\text { Bribery \& Bureaucracy } \\
\text { (BF\&BC) }\end{array}$ & $\begin{array}{l}\text { Economic Growth } \\
\text { (EG) }\end{array}$ & $\begin{array}{l}\text { Political Stability } \\
\text { (PS) }\end{array}$ & $\begin{array}{l}\text { Rule of Law } \\
\text { (PS) }\end{array}$ & $\begin{array}{l}\text { Economic Freedom } \\
\text { (EF) }\end{array}$ & $\begin{array}{l}\text { Transit. Reform } \\
\text { (TR) }\end{array}$ & $\begin{array}{l}\text { Education Index } \\
\text { (CC) }\end{array}$ \\
\hline ALB & 33 & 20.1 & 2.1 & 0.06 & -1.67 & 7.2 & 3.3 & 0.6 \\
\hline $\mathrm{BIH}$ & 39 & $\mathrm{~N} / \mathrm{A}$ & 0.7 & -0.37 & -0.17 & 6.9 & 3.1 & 0.7 \\
\hline BGR & 43 & 19.8 & 1.4 & 0.18 & -0.14 & 7.4 & 3.7 & 0.7 \\
\hline CRO & 48 & 25.1 & -0.8 & 0.61 & 0.26 & 7.1 & 3.7 & 0.8 \\
\hline CZE & 51 & 25.1 & -0.7 & 1.05 & 1.00 & 7.4 & N/A & 0.9 \\
\hline GRC & 43 & 26.2 & -3.3 & -0.20 & 0.44 & 6.9 & $\mathrm{~N} / \mathrm{A}$ & 0.8 \\
\hline HUN & 54 & 16.9 & 2.8 & 0.78 & 0.56 & 7.3 & 3.8 & 0.8 \\
\hline MKD & 45 & 18.2 & 3.1 & -0.37 & -0.20 & 7.1 & 3.5 & 0.6 \\
\hline KOS & 33 & N/A & 2.7 & -0.98 & -0.57 & $\mathrm{~N} / \mathrm{A}$ & 2.8 & $\mathrm{~N} / \mathrm{A}$ \\
\hline MNE & 42 & 18.7 & 2.3 & 0.49 & 0.02 & 7.4 & 3.2 & 0.8 \\
\hline ROM & 43 & 15.3 & 2.4 & 0.15 & 0.11 & 7.6 & 3.7 & 0.7 \\
\hline SRB & 41 & 20.1 & -0.5 & -0.10 & -0.34 & 7.4 & 3.2 & 0.7 \\
\hline SVK & 50 & 22.3 & 1.4 & 1.10 & 0.45 & 7.4 & 3.8 & 0.8 \\
\hline SLO & 58 & 22.8 & -1 & 0.87 & 0.97 & 6.6 & 3.5 & 0.9 \\
\hline
\end{tabular}

Source: Corruption Index - Transparency International Report 2014; Bribery \& Favoritism and Bureaucracy Cost - World Bank, 2014; Economic Growth - IMF, 2014; Government Effectiveness - World Bank, 2014; Political Stability - World Bank, 2014; Economic Freedom Index - Economic Freedom in the World, Report 2014; Transition Reforms - EBRD, 2014; Control of Corruption - World Bank, 2014.

Appendix 1/C

Variable Definitions and Sources

\begin{tabular}{|c|c|c|}
\hline \multicolumn{3}{|r|}{ Variable Definitions and Sources } \\
\hline \multicolumn{3}{|c|}{ Dependent Variables: } \\
\hline Variables: & Source: & Definition: \\
\hline $\begin{array}{l}\text { Corruption } \\
\text { Perception Index } \\
\text { (CPI) }\end{array}$ & $\begin{array}{l}\text { Transparency International } \\
\text { (Annual Report, 2014) }\end{array}$ & $\begin{array}{l}\text { The Corruption Perception Index (CPI) ranks countries based on how corrupt their public sector is perceived to be. } \\
\mathrm{CPI} \text { is a composite index, a combination of polls, drawing on corruption-related data collected by a variety of } \\
\text { reputable institutions. High score of corruption start from } 0 \text { - } 100 \text { and score from } 100 \text { - } 0 \text { are countries with less } \\
\text { corruption level. }\end{array}$ \\
\hline $\begin{array}{l}\text { Bribery and } \\
\text { Favoritism \& } \\
\text { Bureaucracy cost } \\
\text { (BF\&BC) }\end{array}$ & $\begin{array}{l}\text { World Bank: World Economic Forum } \\
2014\end{array}$ & $\begin{array}{l}\text { Bribery, Favoritism and bureaucracy cost means the level of weakness in institution and how many is the role of } \\
\text { institutions to enforce legal framework in overall justice system and process of political stability and economic } \\
\text { development. }\end{array}$ \\
\hline \multicolumn{3}{|c|}{ 2. Independent Variables: } \\
\hline Variables: & Source: & Definition: \\
\hline $\begin{array}{l}\text { Economic Growth } \\
\text { (EG) }\end{array}$ & IMF: World Economic Outlook 2014 & $\begin{array}{l}\text { Real GDP is defined as the value of the total final output (of all goods and services) that is produced in a one year } \\
\text { within a country's boundaries and the growth / decrease of Real GDP is expressed as a percent (\%). }\end{array}$ \\
\hline Political Stability (PS) & $\begin{array}{l}\text { The World Bank } 2014 \text { (Worldwide } \\
\text { Governance Indicators Report) }\end{array}$ & $\begin{array}{l}\text { Political Stability - reflects perceptions of the likelihood that the government will be destabilized or overthrown by } \\
\text { unconstitutional or violent means, including politically-motivated violence }\end{array}$ \\
\hline Rule of Law (RL) & $\begin{array}{l}\text { The World Bank } 2014 \text { (Worldwide } \\
\text { Governance Indicators Report) }\end{array}$ & $\begin{array}{l}\text { Rule of Law - reflects perceptions of the extent to which agents have confidence in and abide by the rules of society, } \\
\text { and in particular the quality of contract enforcement, property rights, the police, and the courts, as well as the } \\
\text { likelihood of crime and violence. }\end{array}$ \\
\hline $\begin{array}{l}\text { Economic Freedom } \\
\text { Index (EF) }\end{array}$ & $\begin{array}{l}\text { Economic Freedom of the World: } \\
\text { Annual Report } 2014\end{array}$ & $\begin{array}{l}\text { Economic Freedom Index - measures the degree of policies and institutions that countries are supportive of economic } \\
\text { freedom. The summary index of Economic Freedom measures the degree of economic freedom in five broad areas, } \\
\text { such as: } 1 \text { Size of Government; } 2 \text { Legal Structure, Security of Property Rights; } 3 \text { Access to Sound Money; } 4 \text { Freedom } \\
\text { to Trade Internationally; } 5 \text { Regulation of Credit, Labor, and Business; }\end{array}$ \\
\hline $\begin{array}{l}\text { Transition Reforms } \\
\text { (TR) }\end{array}$ & EBRD: Transition Report 2014 & $\begin{array}{l}\text { The transition reforms range from } 1 \text { to } 4 \text {, so with } 1 \text { representing little or no change relative to a rigid centrally planned } \\
\text { economy and } 4 \text { representing the standards of an industrialized market economy }\end{array}$ \\
\hline Education Index (EI) & UNDP: Human Development Report & Education Index - is calculated using Mean Years of Schooling and Expected Years of Schooling \\
\hline
\end{tabular}

Source: Authors 